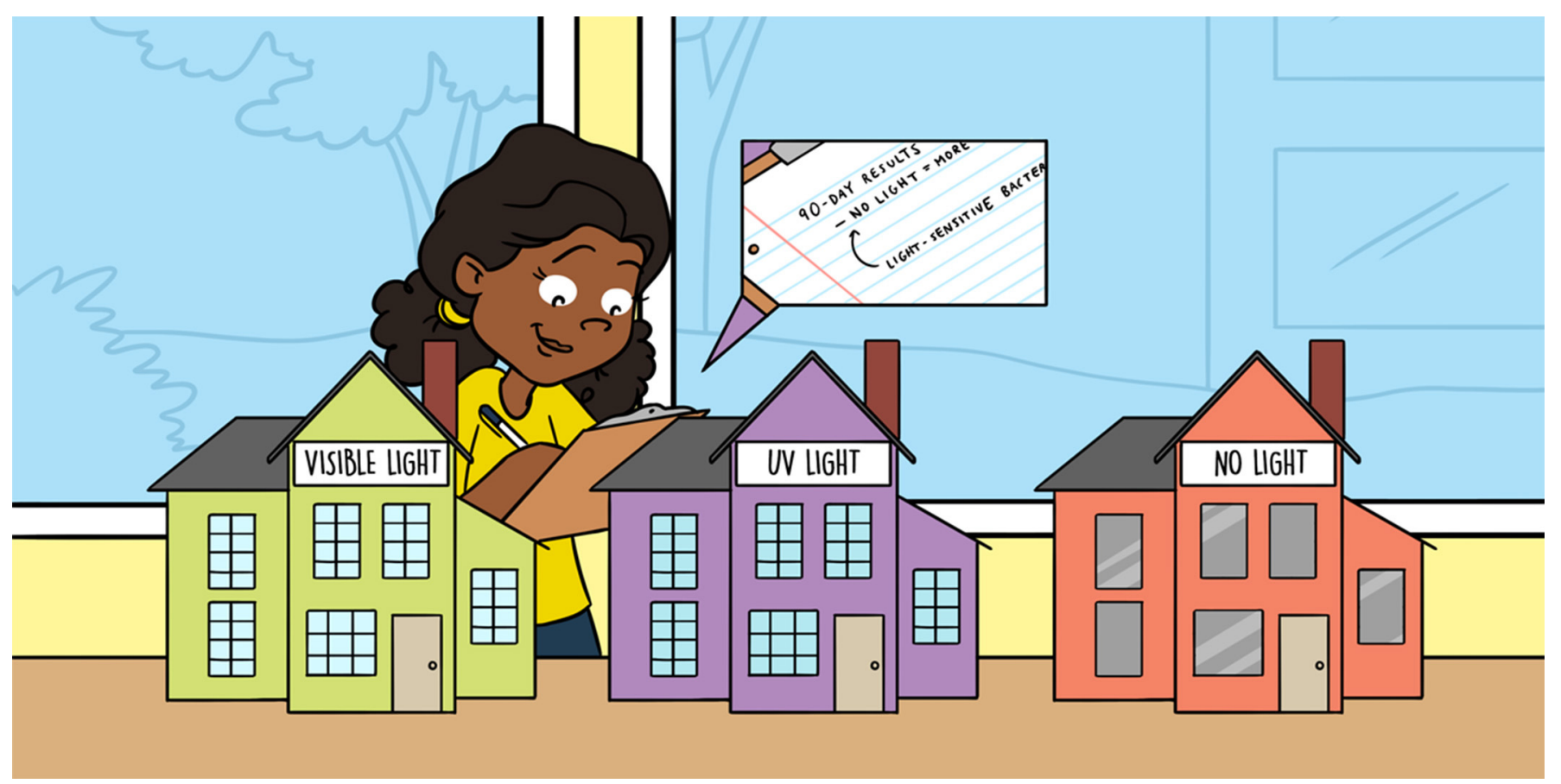

\title{
HOW LIGHT EXPOSURE CHANGES BACTERIAL COMMUNITIES IN HOUSEHOLD DUST
}

\section{Sam Rosenberg, Sue Ishaq *, Julia May and Ashkaan K. Fahimipour}

Biology and the Built Environment Center, University of Oregon, Eugene, OR, United States

YOUNG REVIEWER:

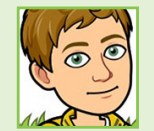

ADAM

AGE: 13
BUILT

\section{ENVIRONMENT}

The collection of buildings, roads, cities, and even parks are the habitat that we have built for ourselves.
Did you know that there are bacteria living in the dust found inside many buildings? Most of these bacteria are harmless, but some might make us sick. We wanted to test how bacteria living in dust would be affected by light: which types would live and which types would die? To test this, we put dust in model offices for 90 days, under different lighting conditions, and measured the effects of light on the bacteria in that dust. We found that certain types of bacteria could not survive indoors when daylight entered rooms through ordinary windows. Understanding how different kinds of microbes thrive or decline in different environments is crucial, as we strive to create buildings of the future that can help us stay healthy, or at least do not make us sick as often.

\section{MICROBES ARE ALL AROUND US}

In much of the world, people spend most of their lives indoors. The collection of buildings, roads, cities, and even parks are the habitat that we have built for ourselves, known as the built environment. 


\section{MICROBE}

A general term used to describe organisms that are very small, like bacteria, fungi, and viruses.

\section{MICROBIOME}

A community of many different types of microbes living together.

When we are inside buildings, it is impossible to avoid coming into contact with the dust that accumulates there. Dust is made up of many different types of materials, including soil, tiny pieces of skin, and fibers from furniture and clothing. Within the dust, there are living communities of microbes called the microbiome, which are made up of organisms so small that you can only see them with a microscope. These dust communities can be made of hundreds of different species of microbes, including bacteria, fungi, and viruses.

Dust and the microbes that live in dust are all around us. Most of these microbial roommates have no effect on us. However, some are helpful, for example those that help us digest our food, while some can be harmful, like the bacteria that make us sick. Knowing more about these dust-living microbes is important to help us understand how our bodies react to our indoor lifestyles. This knowledge could also teach us how to design and use buildings in ways that will help regulate the types of microbes that live there.

\section{WHAT TYPES OF BACTERIA SURVIVE IN DAYLIGHT?}

One thing that might affect indoor microbes is exposure to light. Light can cause chemical reactions within microbes that harm their DNA or the proteins they need to survive and function. A research team at the Biology and the Built Environment Center wanted to perform an experiment to discover how bacteria living in dust would be affected when they were exposed to light [1]. Which types of bacteria would live and which types would die? Understanding how different kinds of microbes are affected in different environments can help us to create buildings that help people stay healthy, or at least do not make us sick as often.

From what was already known about the way light affects bacteria, we came up with a hypothesis before starting our experiments. We hypothesized that: (1) light would kill some of the bacteria living in dust; (2) different types of light would affect bacterial species differently; and (3) bacterial species that are related would be affected by light in similar ways.

\section{BUILDING SMALL MODEL ROOMS TO TEST A HYPOTHESIS}

To test the effects of light on the bacteria living in dust, we first had to obtain some dust! We collected dust from many different buildings and homes and mixed it all together. Mixing the dust together created one big microbial community. We then put small amounts of this mixed dust into 3 light-proof boxes that represented a model for rooms in a building. These boxes each had a window on one side (Figure 1). The windows on each box were made of different types of glass, which 
Figure 1

We created model "offices" for our "dust bunny employees." The window of each box was made from a different material that would let in different types of light. The window in the box on the left only let in ultraviolet (UV) light, the window in the middle box let in no light, and the window in the right box let in visible light that comes from daylight. The bottom graphs show the relative amounts of living bacteria that were present in the dust samples after exposure to light. You can see that there were more bacteria in the box with no light. The graphs also show the relative numbers of bacteria that were similar to the species found outdoors or on humans. These data showed that fewer bacteria survive in light, and the ones that do survive tend to come from the great outdoors.

\section{PROPIDIUM}

MONOAZIDE (PMA)

A chemical dye that sticks to DNA and prevents it from being seen by DNA

sequencing machines.

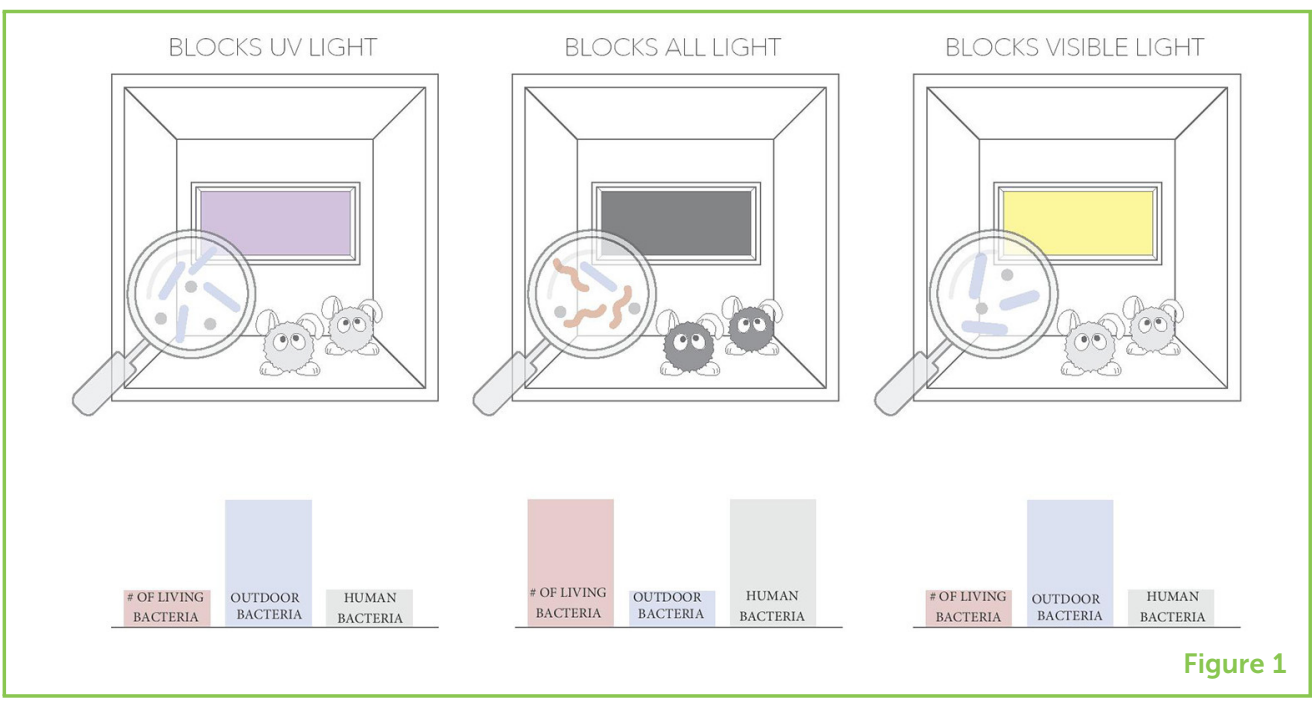

would each let different types of light pass into the boxes (Figure 2). One only let in visible light (the light our eyes can see), like the glass in a regular window in a building. One window let in only ultraviolet light, which is roughly the opposite of a regular window, because it blocked visible light from coming into the box. One window was metal, which did not allow any light to come into the box at all, like a dark room.

To measure the amount of light inside and around these model rooms, automatic sensors were placed inside each box. We also placed a sensor outside of the boxes to measure the sunlight. To keep the boxes in conditions similar to those found inside a real office or classroom, the boxes were placed inside larger, wooden boxes, in which we could control the temperature, the humidity, and the amount of light. This allowed us to keep the conditions the same in all boxes, so the only thing that varied was the amount of light the dust was exposed to. We also had multiple identical samples (called replicates) for each type of light treatment, to make sure the effects we saw were not random. The model rooms were left in this larger box on the roof of a building for 90 days. That is approximately the average amount of time dust spends floating around your home before it is cleaned up. On the roof, the boxes experienced day and night, just like rooms would in a real building.

\section{MEASURING BACTERIA AFTER THE EXPERIMENT}

After the samples spent 90 days on the roof, they were collected and prepared for testing. Each dust sample was split in half: one half was kept as it was, and the other half was treated with a chemical called propidium monoazide (PMA). PMA binds to DNA that has spilled out of dead cells that have broken open. We did this to get the DNA from dead cells "out of the way," so we could make sure we were looking at only 
Figure 2

After 90 days in the model "offices," our "dust bunny employees" looked different from each other. Fewer bacteria were alive in the dust that was exposed to either type of light, compared with the dust samples in the dark boxes. The bacterial species that were still alive in the dust that was exposed to light were similar to the bacteria that are typically found in outdoor environments.

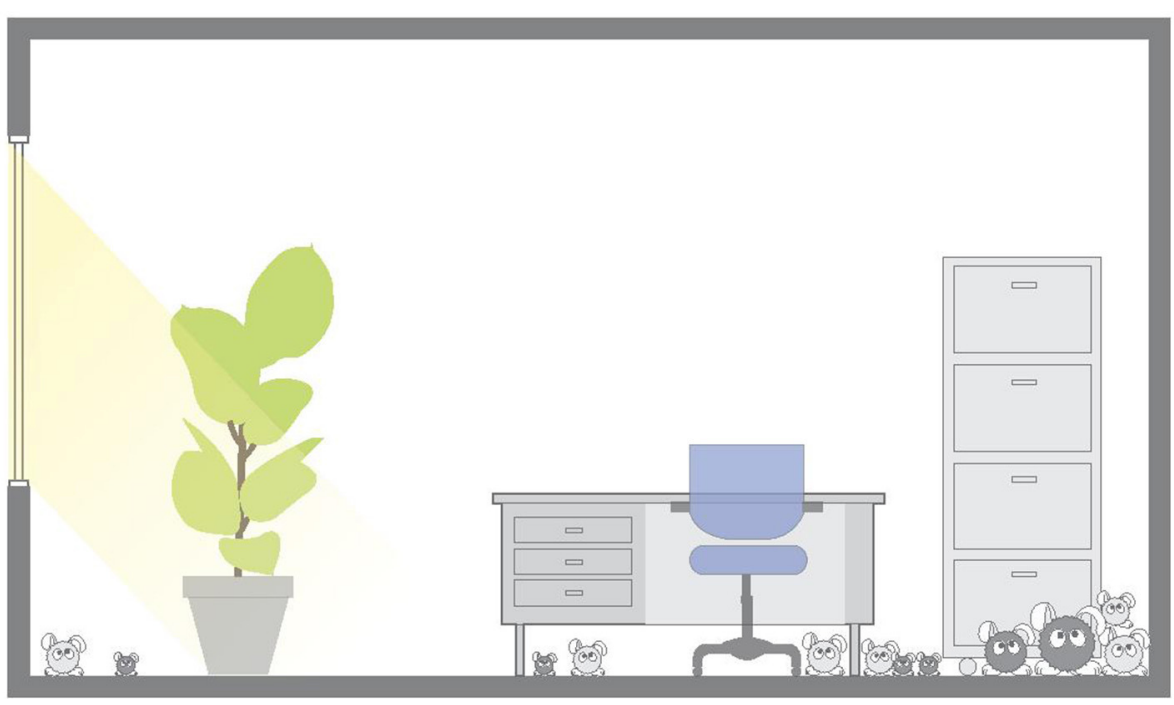

Figure 2

the DNA from living cells in that sample. By comparing the dust sample treated with PMA to the untreated sample, we could compare the DNA that we found in the dust and figure out which types of bacteria died when exposed to light.

We removed the DNA from the bacteria in the regular and PMA-treated dust by breaking open the bacterial cells and washing away anything that was not DNA. Then we used a laboratory technology called DNA sequencing to read the DNA. We compared the bacterial DNA sequences from our dust samples to a database of known bacteria, in order to figure out which types of bacteria were present in the dust. This is kind of like searching for your favorite song on the internet using only some of the lyrics. We compared the types of bacteria in the dust in each of our light treatments to see which types survived the different types of lighting.

\section{LIGHT EXPOSURE CHANGES BACTERIAL COMMUNITIES IN DUST}

We found that light did affect the types of bacteria present in the boxes! The sample that spent 90 days in a dark box contained more different types of bacteria than either box that allowed light to enter through a window (Figure 2). This means that the darkness allowed more diverse species of bacteria to survive, and we think this is because the light-sensitive species were not killed by the light. The bacteria that survived in the dark boxes tended to be similar to those species 
we can find living on human skin, which might not be able to tolerate much sunlight.

The dust from the boxes with windows that let in either visible light or UV light had fewer living bacteria, because not all bacteria like to live in the light (Figure 2). The bacteria that survived the light treatments were similar to the types we can find floating around in the air outdoors, in places where microbes have to deal with light every day. However, there were some differences between the specific types of bacteria found in dust from the boxes that allowed UV light to enter and those that allowed visible light to enter. This suggests that UV light may kill some bacteria that visible light does not kill, and vice versa (Figure 2).

\section{WHAT COULD BE RESPONSIBLE FOR THESE CHANGES?}

We do not think that the large number of bacteria found in the dark boxes was because bacteria reproduced in the dark, since there was not enough water in the environment of the boxes to allow the bacteria to divide. We found that the most prevalent type of bacteria in the dark box sample was from a group called Saccharopolyspora, which is generally found in soil and rural buildings that have a lot of contact with natural environments. Saccharopolyspora may contribute to respiratory diseases that humans get from being indoors and coming into contact with this bacterium, but research is still needed to understand when and why this happens.

Since Saccharopolyspora and other bacteria were missing or found in much lower numbers in the boxes that were exposed to either type of light, this raises the interesting possibility that light may be able to limit or change the growth of different bacteria in buildings where we really care about the presence of bacteria, like in hospitals. Maybe we could design buildings to let in more natural daylight, including both visible and UV light, to keep indoor bacteria at lower levels. However, this study did not test whether any of the bacteria that were sensitive to light were harmful to humans, so we cannot draw conclusions about whether letting in more light would actually benefit human health. The ability of a microbe to survive indoors is complicated and affected by many conditions, including the availability of moisture and how often humans are adding more microbes to the indoor environment. More experimentation is needed to determine the microbe-killing properties of light under wider conditions, such as higher levels of humidity, changes in temperature, changes in the location of the sun, and more. Other experiments need to address the way light-sensitive bacteria might interact with other organisms found indoors, such as viruses, fungi, and protozoans. 


\section{HOW CAN WE APPLY THIS KNOWLEDGE TO BENEFIT HUMANS?}

The results of our experiments suggest that light influences which bacteria can live inside our buildings. This means that architects and lighting professionals who design buildings and determine how much light, and what kinds of light, a room receives might be able to help control which microbial communities we share our homes, offices, and classrooms with. In the future, factors, such as humidity, building location, amount of shade, the number of people in a building, and ventilation, to name a few, must be studied at the same time, to determine the true impact of daylight on microbial communities within the built environment.

\section{ORIGINAL SOURCE ARTICLE}

Fahimipour, A. K., Hartmann, E. M., Siemens, A., Kline, J., Levin, D. A., Wilson, H., et al. 2018. Daylight exposure modulates bacterial communities associated with household dust. Microbiome 6:175. doi: 10.1186/s40168-018-0559-4

\section{REFERENCES}

1. Fahimipour, A. K., Hartmann, E. M., Siemens, A., Kline, J., Levin, D. A., Wilson, H., et al. 2018. Daylight exposure modulates bacterial communities associated with household dust. Microbiome 6:175. doi: 10.1186/s40168-018-0559-4

SUBMITTED: 02 August 2019; ACCEPTED: 11 December 2019;

PUBLISHED ONLINE: 14 January 2020.

EDITED BY: Vishal Shah, West Chester University, United States

CITATION: Rosenberg S, Ishaq S, May J and Fahimipour AK (2020) How Light Exposure Changes Bacterial Communities in Household Dust. Front. Young Minds 7:148. doi: 10.3389/frym.2019.00148

CONFLICT OF INTEREST: The authors declare that the research was conducted in the absence of any commercial or financial relationships that could be construed as a potential conflict of interest.

COPYRIGHT @ 2020 Rosenberg, Ishaq, May and Fahimipour. This is an open-access article distributed under the terms of the Creative Commons Attribution License (CC BY). The use, distribution or reproduction in other forums is permitted, provided the original author(s) and the copyright owner(s) are credited and that the original publication in this journal is cited, in accordance with accepted academic practice. No use, distribution or reproduction is permitted which does not comply with these terms. 


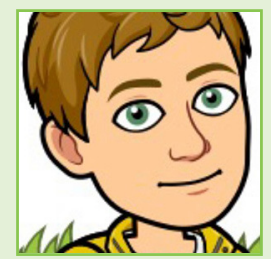

\section{YOUNG REVIEWER}

\section{ADAM, AGE: 13}

Hi, my name is Adam. I live with my parents, older brother, dog, fish, and two birds. I am a big fan of Science and History. I like to draw, write, and read. My favorite sport is soccer (or football). I enjoy swimming in the ocean and playing video games.

\section{AUTHORS}

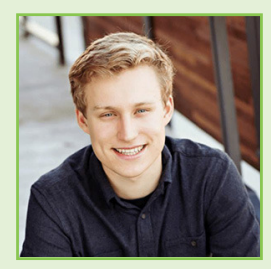

\section{SAM ROSENBERG}

Sam Rosenberg is a recent University of Oregon graduate who focused on biology and computer sciences. He is currently working as a researcher at Pacific Northwest National Lab in Portland, Oregon, studying indoor air quality, building codes, and energy efficiency in residential buildings. His passions are cycling, water sports, environmentalism, reading, and spending time with friends and family. In the future, Sam hopes to improve the world by finding more responsible ways that humans can grow and develop in the world, while reducing our harmful impact.

\section{SUE ISHAQ}

Dr. Sue Ishaq is an Assistant Professor of Animal and Veterinary Science at the University of Maine. Her research background focuses on understanding microbial communities, how they change through time, and how they might alter health. You can follow her updates through www.sueishaqlab.org, or Twitter@DrSuelshaq. *sue.ishaqamaine.edu

\section{JULIA MAY}

Julia May is pursuing her Masters of Architecture at the University of Oregon, with an emphasis in sustainable technology. Before coming to the UO she received her Bachelor of Science in Architectural Studies with a minor in Art from the University of Missouri-Columbia. Her work at the ESBL includes daylight analysis, air filtration research, and designing graphics for the Biology and the Built Environment Laboratory.

\section{ASHKAAN K. FAHIMIPOUR}

Dr. Ashkaan Fahimipour is a scientist with the National Oceanic and Atmospheric Administration, and the Department of Computer Science at the University of California, Davis. He uses mathematics and data analysis to uncover patterns in complex biological datasets, with interests ranging from the functions encoded by bacterial DNA to the ways that fish find food. 